\title{
ASSESSMENT OF TECHNOLOGY TRANSFER OFFICE PERFORMANCE FOR VALUE CREATION IN HIGHER EDUCATION INSTITUTIONS
}

\author{
Jelena STANKEVIČIENE ${ }^{1}$, Lidija KRAUJALIENE ${ }^{2}$, \\ Agnė VAICIUKEVIČIŪTE் $\dot{E}^{3}$ \\ Faculty of Business Management, Vilnius Gediminas Technical University, \\ Saulètekio al. 11, LT-10223 Vilnius, Lithuania \\ E-mails: ${ }^{1}$ jelena.stankeviciene@vgtu.lt (corresponding author); \\ 2lidija.kraujaliene@vgtu.lt; 3agne.vaiciukeviciute@vgtu.lt
}

Received 28 March 2017; accepted 13 November 2017

\begin{abstract}
Innovative activities, knowledge exchange, patenting and commercialization of know-how are crucial to the value creation process in higher education institutions and other research organizations. The article analyses the technology transfer performance indicators of value creation. The methodology to identify and assess the technology transfer activities with the highest impact on created value are proposed in the paper. The following research methods were invoked: FARE method, allowed to calculate weights of each technology transfer performance indicator, when TOPSIS method redress all different indicators' results and rank universities. The application of the proposed methodology was based on empirical data collected from Lithuanian universities. The results of the study reveal the importance of science business partnerships, TTO competence and scientists' trust of TTO, applying particular technology transfer policy. The obtained results would be beneficial for universities technology transfer policy formation to maximize universities created value.
\end{abstract}

Keywords: technology transfer office (TTO), value creation, FARE method, TOPSIS method, higher education institutions (HEI), university.

JEL Classification: G32, O32, O34.

\section{Introduction}

Innovation is a key driver of economic growth (Ouyang et al. 2017). Governments are focused on nurturing innovation, developing advanced manufacturing as an essential element of Industry 4.0 activities. During recent years, innovations and technology transfer processes became priorities for the universities. They help to develop the next generation of technologies and increase the number of high-growth startups. Governments require universities to incorporate excellent management and entrepreneurial abilities to commercialize the intellectual property of universities, to develop new spin-offs and start-up companies. The need for quantitative evaluation of effectiveness of technology transfer processes at universities is in a great demand. 
The aim of the paper is to develop the principles of the assessment of technology transfer activities and benchmarking of key indicators as well as to create basic multicriteria model to assess the effectiveness of technology transfer offices' activities. The assessment methodology of how institutional and regional factors impact on value creation of technology transfer process and commercialization in higher education institutions are developed and implemented in the article. The patent applications were proposed as the main performance measure of technology transfer activities of universities, different organizational structures of technology transfer offices were compared as well. The multicriteria decision methods create the core of the technology transfer efficiency assessment model. Research methods include Factor Relationship (FARE) method to estimate the weights of technology transfer process indicators and TOPSIS method, which allows using calculated weights for technology transfer office performance indicators and ranking universities with the best results. The data for empirical implementation of the prosed assessment model was gathered for the period of three years 2011-2013 (resent available data). The primary data was collected by interviews from focus group - the managers of technology transfer offices and from universities annual reports.

Results of the research would be beneficial for universities' policy formation regarding technology transfer activities, technology transfer models, strategic approaches, intellectual property brokerage functions, science-business collaboration. This research has provided a useful body of knowledge on the concept of the assessment of the effectiveness of technology transfer process at universities, especially in the areas of application of multicriteria decision methods in the evaluation of technology transfer activities.

The rest of the paper is organized as follows. The first section provides a theoretical background of the technology transfer and value creation processes in higher education institutions and reviews the necessary conditions. The second section describes the data sample and discusses the empirical results. The last section presents the evaluation results of technology transfer process at seven main HEIs operating in Lithuanian regions and puts forward some concluding remarks.

\section{Theoretical discussion: technology transfer as an instrument of value creation of higher education institutions}

Performance management of technology transfer office (TTO) is important indicator to show the effectiveness and abilities of universities to implement knowledge and technology transfer as well as commercialization activities. In this article, the performance has the meaning of organizational system performance as a competence or capacity, and the number of actions being performed, or by the quality of achieved goals (Van Dooren et al. 2010). Technology transfer is explained as the process of sharing and disseminating knowledge, skills, scientific discoveries, production methods, and other innovative solutions among science-business organizations as universities, government agencies, private companies, and other institutions (Audretsch et al. 2013).

University's technology transfer offices connect universities and industry to support the mechanisms of technology transfer and commercialization (Hui-I et al. 2012). The relationship between globalization of academic innovation and university technology 
transfer has been previously investigated by various scholars (Breznitz, Etzkowitz 2017; Chatterji 2016). According to Etzkowitz and Göktepe-Hultén (2016) universities, through the commercialization of technology, have developed the ability to influence regional economic growth. Zhang and Gallagher (2016) pointed out four main drivers for technology transfer from the global innovation system to China: global market formation policy, international mobilization of talent, the flexibility of manufacturing in China, and belated policy incentives from China's government. Lee et al. (2017) explored the technology transfer and established a comprehensive framework for the factors which influence on-time completion of technology transfer for suppliers and buyers according to technology transfer agreements.

There are two main technology transfer models in the world: European and American. According to American model technology transfer offices operate outside universities. However, for European academic society it is very important the trust between technology transfer officers and scientists, so that it is why European universities have technology transfer offices inside universities. Gerbin and Drnovšek (2013) used empirical data to point to specific differences in the domain between Europe and USA, their finding points to the weaknesses of the highly monetized US business model given the tendencies of the European industry to emulate this model.

The main function of the technology transfer office is to moderate the relationship between scientists and business in technology management process. Miller et al. (2016) emphasised the complex network of regional stakeholders in technology transfer process, which resulted in quadruple helix models where the triple helix model of academia, industry and regional government now includes societal based innovation users as a fourth helix. The improvement of science-business cooperation is possible by providing technical consultations or related services (Carlsson, Fridh 2002; Fritsch, Schwirten 1999). Battaglia et al. 2017 identified three organizational structures adopted by technology transfer offices to grow externally: a network, a Strong Hub and a Light Hub structure.

In case of universities it is important the collaboration between scientists and the staff of technology transfer office. The evidence from the research conducted by Huyghe et al. (2016) confirmed that awareness of technology transfer office is greater among researchers who possess experience as entrepreneurs, closed many research and consulting contracts with industry partners. Boh et al. (2016) indicated that graduate and post-doctoral students are important participants in university spinoffs and proposed a typology of spinoff development with four pathways, based on the varying roles of faculty, experienced entrepreneurs, $\mathrm{PhD}$ /post-doctoral students, and business students. Fai et al. 2017 found out correlations between the maturity level of the technology transfer offices mission statements and their governance structures and suggested a novel technology transfer office typology and provided recommendations for developing countries. Audretsch et al. (2016) brought the perspective of entrepreneurial finance into the realm of technology transfer and identified aspects of technology transfer with regard to supply-side public policies. Ayoub et al. (2017) provided evidence that startups are smaller by two full time equivalent employees, generate 1.7 times higher losses 
and have a nearly three times lower return on capital than science-based entrepreneurial firms with comparable characteristics in the first 5 years after foundation.

The research question raised in the paper was how to evaluate the potential for performance of technology transfer office and find out the main factors which influence the effectiveness of technology transfer process. The concept of maximizing shareholder value was used to elucidate determinants of technology transfer performance. According to Van Dooren et al. (2010), the following factors: financial, human resource, capital and information technology management, should be assessed.

Numerous studies (Keller 2004; Araújo, Teixeira 2014) have analysed how employees of technology transfer office influence the technology transfer performance. According to the empirical evidence, the adoption of a technology can be facilitated by skills of human capital endowment. Industry cooperation must be driven by human resource which is one of the more important factor of the success of technology transfer process. This evidence is conveyed by the words of Thursby, J. B. and Thursby, M. C. (2001). By Gregorio and Shane (2003), the core role for good knowledge transfer to the industry, on the example by the evolution of the USA's universities during last 20 years, in universities plays next factors (which depend on human resource): orientation toward $R \& D$, excellent IP, and the power of the administration. Leadership and information influence the management capacity. Leaders have the core role to make decisions, to show the right directions, to develop institution's mission, vision and strategy and to bring the right message to staff.

Research capital in terms of university-industry cooperation, relies much on activities by university researchers' groups, technology transfer office and industry staff (Etzkowitz, Leydesdorff 2000). Absorptive capacity is important factor also for the industry sector reflecting the ability to use technologies effectively in the market. Connectedness is significant factor for industry and universities technology transfer office work. Environments, created around technology transfer activities, foster interpersonal relationships and can be conductors in the knowledge transfer process (Santoro, Bierly 2006). Sherwood and Covin (2008) wrote that success of knowledge acquisition between university and industry relies on trust between sending and receiving party. Through experience parties become understandable about collaboration opportunities, how to manage the organization and to get benefit from it (Arvanitis, Woerter 2009; Sherwood, Covin 2008).

Patents actually contribute to the estimation of universities' academic performance. IP is about how to let the knowledge of an organization work for it and have it created value (Roberts 1999). Fitzgerald and Cunningham (2016) from the quantitative analysis found moderate positive correlations between patents granted and number of university technology transfer office mission statement components.

Value creation is relating also with networking within universities, government investments, structural funds and economic indicators, emigration, strategic management concepts, market oriented students, management methods (Kahraman et al. 2013; Ivanauskas et al. 2015; Mainardes et al. 2015). Efficiency in universities also could be evaluated by DEA method or implementing complex proportional assessment (Nazarko, Saparauskas 2014; Stefano et al. 2015). 


\section{Research methodology}

In recent years previous scholars (Mardani et al. 2015a, 2015b; Zavadskas et al. 2014; Kabak, Dagdeviren 2014; Baležentis, T., Baležentis, A. 2014; Hashemkhani Zolfani et al. 2016a) developed, proposed and applied different multi-criteria decision-making methods (Hashemkhani Zolfani et al. 2016b; Keshavarz Ghorabaee et al. 2016; Madic et al. 2016) for solving complicated problems in decision making issues. On pursuance effectively address the research problem the following research stages (Fig. 1) were taken. First, a technology transfer performance assessment model was designed based on the data collected from the quantitative interviews with the managers of technology transfer offices. Second, Factor Relationship (FARE) method to estimate the weights of technology transfer process indicators was used. Finally, the TOPSIS method, which allows using calculated weights for technology transfer office performance indicators and ranking universities with the best results, was invoked.

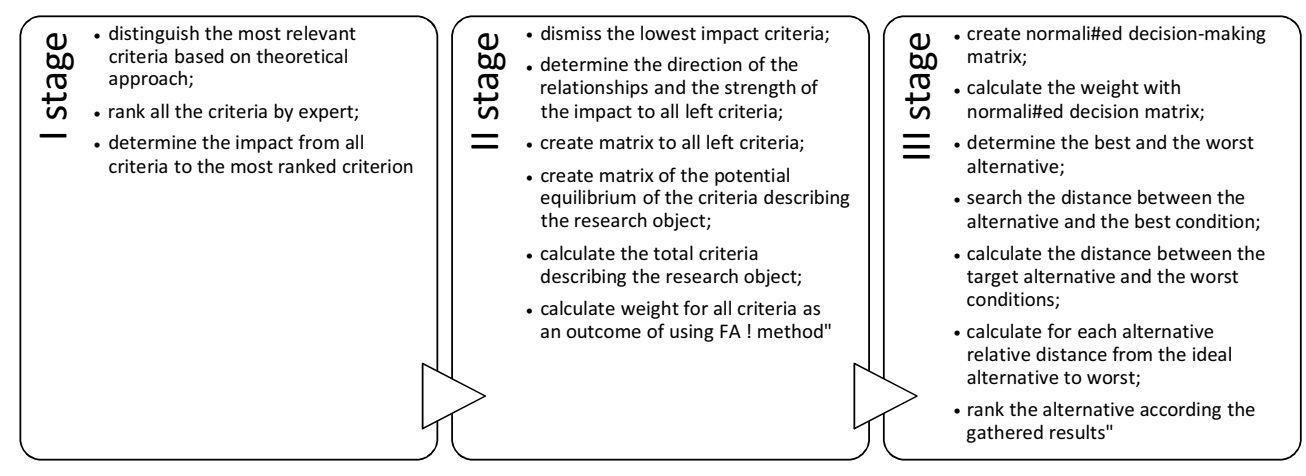

Fig. 1. Structure of the research

Source: compiled by authors.

\subsection{Performance indicators of technology transfer offices in Lithuania}

The performance will be analysed by empirical analyses of technology transfer offices in Lithuanian universities. Intended variables categories, data sources, descriptions and names for the model of the research will be:

- patent applications (number generated per university),

- technology transfer offices (employees, tasks, PhD-share),

- 21 Lithuanian universities (funding, students, publication -3 years average per researcher),

- regional aspects (GDP per capita, industry concentration, start-up's).

The research method is including three categories of variables representing Lithuanian universities, technology transfer office and regional indicators of technology transfer process. Next, the table of variables and measurement of the research is presented (Table 1). 
Table 1. Variables and measurement of the research method (adapted from Hulsbeck et al. 2011)

\begin{tabular}{llll}
\hline Category & \multicolumn{1}{c}{ Name } & \multicolumn{1}{c}{ Description } & \multicolumn{1}{c}{ Source } \\
\hline Endogenous & $\begin{array}{l}\text { Patent } \\
\text { applications }\end{array}$ & 3 year average (2011-2013) & Lithuanian Patent Office \\
\hline TTO & Employees & $\begin{array}{l}\text { Number of employees in the TTO } \\
\text { (full time work) }\end{array}$ & $\begin{array}{l}\text { Interviews with TTO } \\
\text { Managers }\end{array}$ \\
\cline { 2 - 4 } & Tasks & $\begin{array}{l}\text { The number of tasks per employee } \\
\text { at TTO }\end{array}$ & $\begin{array}{l}\text { Interviews with TTO } \\
\text { Managers }\end{array}$ \\
\cline { 2 - 4 } & PhD Share & $\begin{array}{l}\text { The number of full time working } \\
\text { researchers with PhD academic } \\
\text { degree }\end{array}$ & $\begin{array}{l}\text { Interviews with TTO } \\
\text { Managers }\end{array}$ \\
\hline UNI & Funding & $\begin{array}{l}\text { 3 year average (2011-2013) } \\
\text { of funding per one researcher }\end{array}$ & University report \\
\cline { 2 - 5 } & Students & $\begin{array}{l}\text { The number of students in } \\
\text { University }\end{array}$ & $\begin{array}{l}\text { Association of Lithuanian } \\
\text { Higher Education Institutions } \\
\text { for the General Admission }\end{array}$ \\
\cline { 2 - 5 } & Publication & $\begin{array}{l}\text { 3 year average (2011-2013) of } \\
\text { publications per researcher and year }\end{array}$ & University report \\
\hline REG & $\begin{array}{l}\text { GDP per } \\
\text { capita }\end{array}$ & $\begin{array}{l}\text { Regional gross domestic product per } \\
\text { capita }\end{array}$ & $\begin{array}{l}\text { The Lithuanian Department } \\
\text { of Statistics }\end{array}$ \\
\cline { 2 - 5 } & $\begin{array}{l}\text { Industry } \\
\text { concentration }\end{array}$ & $\begin{array}{l}\text { Industry concentration coefficient } \\
\text { based on the number per employees } \\
\text { in certain regional industry }\end{array}$ & $\begin{array}{l}\text { The Lithuanian Department } \\
\text { of Statistics }\end{array}$ \\
\cline { 2 - 5 } & Start-up's & $\begin{array}{l}\text { The number of Start-up's of certain } \\
\text { University }\end{array}$ & $\begin{array}{l}\text { Interviews with TTO } \\
\text { Managers }\end{array}$ \\
\hline
\end{tabular}

Source: adapted by authors from Hulsbeck et al. (2011).

The sequence of estimated research started with collecting and analysing the data (based on Hulsbeck et al. 2011): (1) TTO (telephone surveys): the number of employees working in technology transfer office (FTE - full time equivalent), tasks measured per employee, the number of $\mathrm{PhD}$ academic degree employed in technology transfer office; (2) universities are going to be characterized by research and teaching (data collected from universities annual reports and the Association of Lithuanian Higher Education Institutions for the General Admission): funding (3 year average for researcher) data, the number of students, publications ( 3 year average publications for researcher) data; (3) regional aspects of economic activities: GDP per capita (regional gross domestic product per capita - from regional statistics) data found from Department of Statistics, as well as Industry concentration (the number of workers in the regions), entrepreneurial activity - Start-up companies at universities. Pfeffer (1995) demonstrates that workforce can perform well by effective management that requires time period. That is why the period selected for the research is three years: 2011-2013 (the recent available data). 


\subsection{FARE method for technology transfer office performance weights assessment}

Factor relationship method (FARE) (Ginevičius 2011) was proved as credible as other multi-criteria methods. The main difference between this method and others is the possibility with less initial information have wider range of calculations compared, for instance, with Analytic Hierarchy Process (AHP) method. Authors already successfully applied FARE method in HEIs valuation (Stankevicienè, Vaiciukeviciute 2016). In the case of technology transfer office performance evaluation for value creation in HEIs where are lots of criteria this method was chosen as the one which can capture the most rigorous results in the context of available data. In order to use this method, the fallowing sequence (Table 2) needs to be applied:

Table 2. The sequence of FARE method

I. The frame of method application - based on the Systems Theory all elements needs to be interconnected one way or another

II. Two main implications need to be considered:

1. Firstly, total impact on the investigation increase when the number of criteria that transfers its potential increase.

2. Secondly, the opposite reaction will occur when the number of criteria that transfers its potential decrease.

Then the equation would be: $P=S(m-1)(1)$ where $\mathrm{P}$ is the criterion impact; $S$ is the maximum value of evaluation used; $m$ is the number of the criteria

III. The experts in the field evaluate each criterion by seeking to ascertain the main criterion in comparison with other criteria

IV. The experts ascertain the scope of the transfer by defining the impact of the criteria $a_{i}$ on the main criterion: $a_{1 i}=S-\widetilde{a_{1 i}}(2)$, where $a_{i}$ is the impact of $\mathrm{i}$-th criterion on the first major criterion; $\widetilde{a}_{i}$ is the part of i-the criterion's potential impact transferred to the major criterion

V. Then based on Kendall coefficient the coherence between the experts' opinions must be verified

6. All the interconnections between the criteria, its strength, together with the relationships created at the first stage, are evaluated analytically

7. The direction - the lower rank criterion transfers a part of its potential to a higher rank criterion. The impact $-\widetilde{a_{i}}= \pm\left(\widetilde{a_{1 i}}-\widetilde{a_{i 2}}\right)$ (3), has a structure $a_{i j}=-a_{i j}$ where the matrix substantiates the total dependence of a criterion on other criteria

8. Then the impact $P_{i}$ can be calculated by: $P_{i}=P_{i}-m \times a_{1 i}-m$ (4)

9. Where the total impact of each criterion is collated with the total potential $\left(P_{S}\right)$ of the criteria: $P=m \times P=m S(\mathrm{~m}-1)(5)$

10. Now the factual potential can be found by formula: $P_{i}^{f}=P_{i}+$, where $P_{i}^{f}$ (6) is the factual impact of the i-th criterion; $P_{i}$ is the total impact produced by the i-th criterion or itsl dependency on other criteria

11. Finally, the values $w_{i}$ of the total impact of the criteria can be estimated:

$w_{i}=\frac{P_{i}^{f}}{P_{S}}=\frac{P_{1}-m a_{1 i}+S(m-1)}{m S(m-1)}$

Source: compiled by authors from Ginevičius (2011). 


\subsection{TOPSIS method for technology transfer office performance assessment}

The Technique for Order of Preference by Similarity to Ideal Solution (TOPSIS) is a multi-criteria decision analysis method created by Hwang and Yoon (1981). This method selects the best alternative that has the shortest distance from positive-ideal solution (PIS) and the longest distance from the negative-ideal solution (NIS) (Wang, Chang 2007). Method helps theoretically ascertain the highest (mostly desirable) and the lowest (mostly avoidable) values for all criteria. Therefore, the method wisely used (Behzadian et al. 2012; Choudhury 2015; Ding, Zeng 2015; Song, Zheng 2015; Zolfani et al. 2015; Zavadskas et al. 2016) by decision-makers to rank variety of alternatives estimated on a group of conflicting and disproportionate criteria. The sequence of the fallowing steps of the TOPSIS method should be implemented as indicated in the Table 2.

Table 2. The sequence of TOPSIS method

1. Creating normalized decision-making matrix consisting of $m$ alternatives and $\mathrm{n}$ criteria, with the intersection of each alternative and criteria given as $x_{i j}$, with the matrix $\left(x_{i j}\right) m \times n$;

$$
\bar{x}_{i j}=\frac{x_{i j}}{\sqrt{\sum_{i-1}^{m} x_{i j}^{2}}}
$$

2. Calculate the weighted with normalized decision matrix: $\hat{x}_{i j}=\bar{x}_{i j} w_{j}$

3. Determine the best and the worst alternative from all alternatives: $x_{p j}=\max _{i} x_{i j}$ (10); $x_{p j}=\min _{i} x_{i j}(11) ; x_{b j}=\max _{i} x_{i j} \quad(12) ; x_{b j}=\min _{i} x_{i j}$

4. Calculate the distance between the alternative $i$ and the best condition

$$
d_{p i}=\sqrt{\sum_{j=1}^{n}\left(x_{i j}-x_{p j}\right)^{2}}
$$

5. Calculate the distance between the target alternative $i$ and the worst condition

$$
d_{b i}=\sqrt{\sum_{j=1}^{n}\left(x_{i j}-x_{b j}\right)^{2}}
$$

6. Calculate for each alternative relative distance from the ideal alternative to worst

$$
K_{i}=\frac{d_{b i}}{d_{p i}+d_{b i}}(16)
$$

7. Rank the alternatives according to gathered results

Source: compiled by authors.

\section{Research findings and discussion}

I stage. Twenty-five experts from seven main HEIs operating in Lithuanian regions (Vilnius, Kaunas, Klaipeda etc.) were interviewed during the research. The target group was experts working in innovation, science-business, technology transfer sphere. Participants of the research were asked to evaluate 16 indicators that are the most crucial to the successful performance (Table 3), that directly influence technology transfer office performance and consequently all value creation process within HEIs. According 
to the previously analysed scientific literature, the value of technology transfer office performance should be assessed taking into consideration university, technology transfer office and regional indicators that describe internal and external elements that mostly influences the process of technology transfer and commercialization in the context of HEIs. In order to understand which criteria, have the highest influence to the technology transfer office performance for value creation in HEIs FARE method was applied.

Table 3. Criteria that influences TTO performance

\begin{tabular}{ll}
\multicolumn{1}{c}{ National patent applications } & \multicolumn{1}{c}{$\begin{array}{c}\text { The number of publications } \\
\text { for the one researcher }\end{array}$} \\
\hline European and international patents applications & Income from national projects (EUR) \\
\hline National patents & Income from international projects (EUR) \\
\hline The number of employees at TTO & Income from contract works (EUR) \\
\hline The number of Start-up's & Funding per one researcher (EUR) \\
\hline The number of tasks for employee at TTO & The number of students at universities \\
\hline The number of publications at university & GDP per capita in Lithuania \\
\hline The number of researchers at university & $\begin{array}{l}\text { Industry concentration based on the number } \\
\text { of employees (in units) in university region }\end{array}$ \\
\hline
\end{tabular}

Source: compiled by authors.

Firstly, the experts evaluated all the criteria to identify the interconnections within criteria (Table 4) where the ranking amplitude from 1 to 16 was ascertained. The criterion that was determined was the most influential on overall technology transfer commercialization and technology transfer performance in accordance with others.

Table 4. The ranks of system's criteria assigned by experts

\begin{tabular}{lcccccccccccccccc}
\hline Criterion & 1 & 2 & 3 & 4 & 5 & 6 & 7 & 8 & 9 & 10 & 11 & 12 & 13 & 14 & 15 & 16 \\
\hline Rank & 16 & 3 & 15 & 8 & 6 & 12 & 11 & 4 & 7 & 9 & 5 & 1 & 2 & 14 & 13 & 10 \\
\hline
\end{tabular}

Source: compiled by authors.

Then, the participants of the research determined the scope of criteria impact (Table 5) the highest rank criterion. The scale of interrelationship between the system's criteria was used from 1 as almost none impact to the 10 - absolute impact of the criteria (Ginevičius 2011). The main idea behind these ranks that criterion with lower ranks consequently has smaller impact on the criteria that was ranked higher.

Table 5. The relationship between the sixteenth main criterion determined by the experts

\begin{tabular}{ccccccccccccccccc}
\hline Criteria & 1 & 2 & 3 & 4 & 5 & 6 & 7 & 8 & 9 & 10 & 11 & 12 & 13 & 14 & 15 & 16 \\
\hline 12 & +1 & +7 & +1 & +5 & +1 & +2 & +3 & +4 & +2 & +6 & +9 & & +8 & +1 & +1 & +2 \\
\hline
\end{tabular}

Source: compiled by authors. 
We can see that the main criterion according to experts' opinion is criterion $12^{\text {th }}$ that represents income from contract works. The calculated concordance coefficient was also considerable with the value of 0.563 . That means that experts opinion was sufficiently consistent. After these calculations the relations between the remaining criteria were analytically estimated. Based on the formula (2), the part of the criterion's impact was transferred to the first criterion (Table 6).

Table 6. The part of the criterion potential impact transferred to the 12 main criterion determined by the experts

\begin{tabular}{lcccccccccccccccc}
\hline Criteria & 12 & 11 & 13 & 2 & 10 & 4 & 8 & 7 & 16 & 9 & 6 & 5 & 3 & 1 & 15 & 14 \\
\hline 12 & & +1 & +2 & +3 & +4 & +5 & +6 & +7 & +8 & +8 & +8 & +9 & +9 & +9 & +9 & +9 \\
\hline
\end{tabular}

Source: compiled by authors.

Thus, the graph (Fig. 2) visually explain that a criterion of the higher rank took a part of the lower rank criterion's potential, because the criterion of a lower rank has the smaller impact on the criteria having higher ranks so, it should transfer a larger part of its potential impact to them. So, experts determined that criteria $10^{\text {th }}$ were ranked by number +6 which means that the effect on our main criterion $12^{\text {th }}$ from criteria $10^{\text {th }}$ is higher than average. Therefore, criteria $10^{\text {th }}$ should transfer only potential impact equal to +4 . As shown in Table 4, the first criterion is ranked $12^{\text {th }}$, while the $13^{\text {th }}$ criterion is ranked second. It follows that the first criterion should transfer a part of the potential of its impact to the second criterion. This is confirmed in the Figure 3 where based on this idea all relationship is calculated. In the graphical relationships between criteria, can be seen that all the criteria fulfil the precondition of FARE method that all subsets of a set and their elements should be connected in some way.

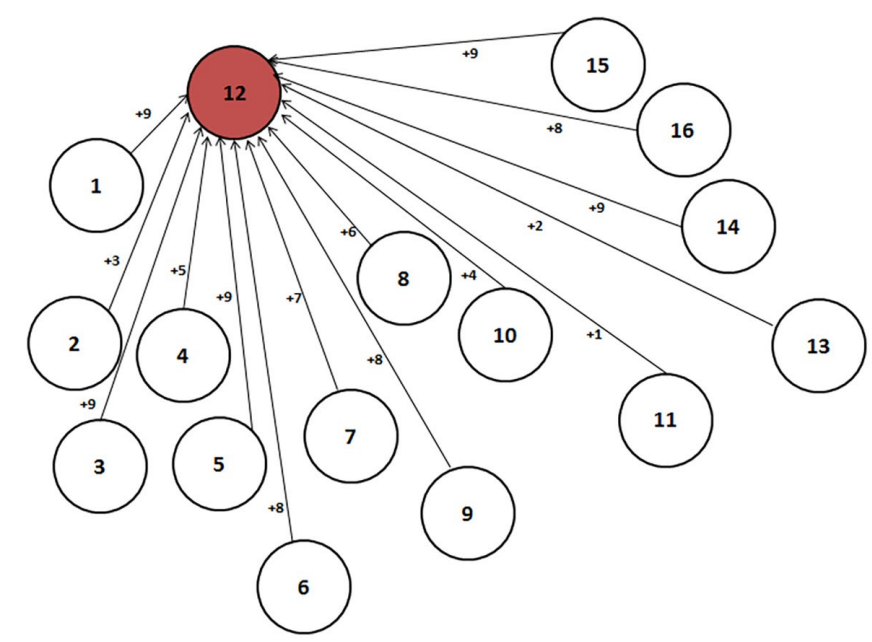

Fig. 2. The relationship between the main (twelve) criterion and other system's criteria Source: compiled by authors. 


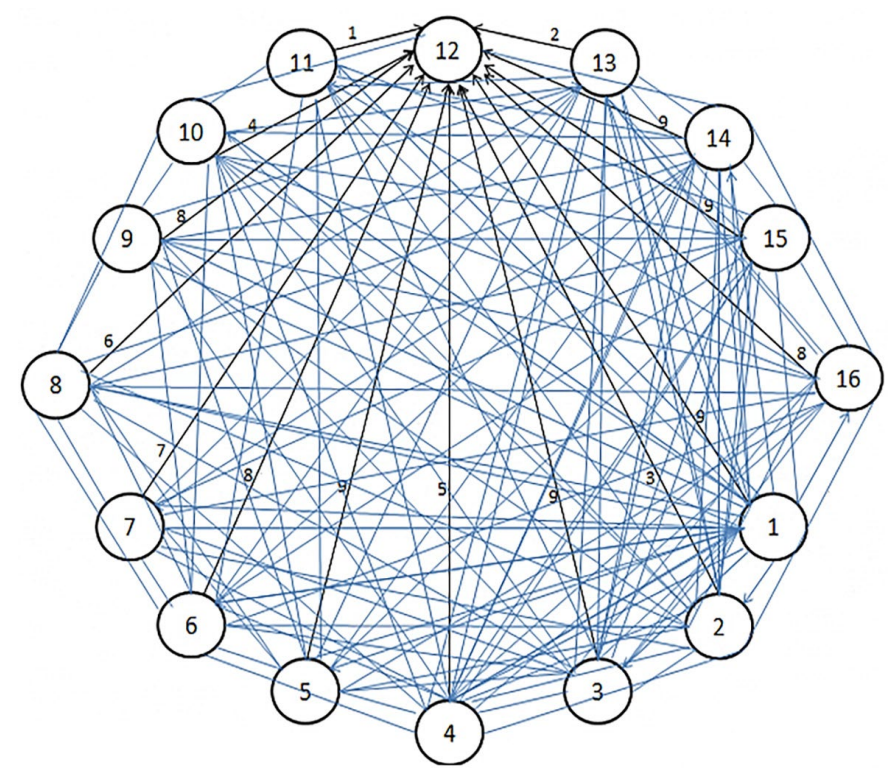

Fig. 3. The graphical relationships between criteria and strength of the impact to twelfth Source: compiled by authors.

II stage. At this stage the lowest impact criteria were dismissed, due to experts' valuation and our calculations the impact of last 8 criteria is significantly small (Table 4). Therefore, the compromise was made and eight the most influential criteria were distinguished and their weights were calculated.

The direction is denoted by a plus or a minus; showing that the criterion considered either influences another system's criterion or depends on it. A negative relationship shows that the criterion considered is less significant than the criterion to which it is related. Therefore, it transfers a part of its potential to it. When it is positive, the considered criterion accumulates the potential of another criterion, thereby increasing the potential of its impact. Then, the matrix based on calculations (Fig. 4) was calculated (Table 7).

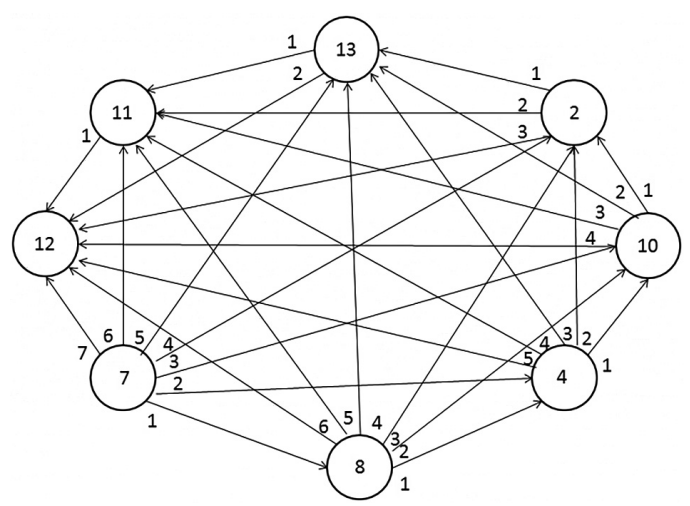

Fig. 4. The direction of the relationships and strength of the impact Source: compiled by authors. 
Table 7. A summary matrix of the potential equilibrium of the criteria describing the research object

\begin{tabular}{ccccccccc}
\hline Criteria group & \multicolumn{7}{c}{ Criteria group } & \\
\cline { 2 - 9 } & 12 & 11 & 13 & 2 & 10 & 4 & 8 & 7 \\
\hline 12 & & +1 & +2 & +3 & +4 & +5 & +6 & +7 \\
\hline 11 & -1 & & +1 & +2 & +3 & +4 & +5 & +6 \\
\hline 13 & -2 & -1 & & +1 & +2 & +3 & +4 & +5 \\
\hline 2 & -3 & -2 & -1 & & +1 & +2 & +3 & +4 \\
\hline 10 & -4 & -3 & -2 & -1 & & +1 & +2 & +3 \\
\hline 4 & -5 & -4 & -3 & -2 & -1 & & +1 & +2 \\
\hline 8 & -6 & -5 & -4 & -3 & -2 & -1 & & +1 \\
\hline 7 & -7 & -6 & -5 & -4 & -3 & -2 & -1 & \\
\hline Total & -28 & -20 & -12 & -4 & +4 & 12 & 20 & +28 \\
\hline
\end{tabular}

Source: compiled by authors.

When we have the entire matrix, the total potential impact $P_{i}$ by using formula (4) was calculated based on the data presented in the first row of the matrix. The results can be seen below in Table 8. As can be seen the total effect (dependence) should be equal zero which means that the results are compatible with each other.

Now in order to calculate weights $w_{i}$ based on formula (5) and formula (6) the actual total impact $P_{i}^{f}$ with the actual total impact of each criterion of the system on the research object were found (Table 8).

Table 8 . The results obtained in calculating the total effect (dependence) of the criteria describing the research object

\begin{tabular}{|c|c|c|c|c|c|c|c|c|c|c|}
\hline \multirow{2}{*}{$\begin{array}{l}\text { Criteria } \\
\text { group }\end{array}$} & \multicolumn{6}{|c|}{ Criteria group } & \multirow[b]{2}{*}{8} & \multirow[b]{2}{*}{7} & \multirow{2}{*}{$\begin{array}{c}\text { Total Effect } \\
\text { (Dependence) } P_{i}\end{array}$} & \multirow{2}{*}{$P_{i}^{f}$} \\
\hline & 12 & 11 & 13 & 2 & 10 & 4 & & & & \\
\hline 12 & & +1 & +2 & +3 & +4 & +5 & +6 & +7 & +28 & +98 \\
\hline 11 & -1 & & +1 & +2 & +3 & +4 & +5 & +6 & +20 & +90 \\
\hline 13 & -2 & -1 & & +1 & +2 & +3 & +4 & +5 & +12 & +82 \\
\hline 2 & -3 & -2 & -1 & & +1 & +2 & +3 & +4 & +4 & +74 \\
\hline 10 & -4 & -3 & -2 & -1 & & +1 & +2 & +3 & -4 & +66 \\
\hline 4 & -5 & -4 & -3 & -2 & -1 & & +1 & +2 & -12 & +58 \\
\hline 8 & -6 & -5 & -4 & -3 & -2 & -1 & & +1 & -20 & +50 \\
\hline 7 & -7 & -6 & -5 & -4 & -3 & -2 & -1 & & -28 & +42 \\
\hline Total & -28 & -20 & -12 & -4 & +4 & 12 & 20 & +28 & 0 & 560 \\
\hline
\end{tabular}

Source: compiled by authors.

Finally based on formula (7) the normalized values $w_{i}$ of the potential of the total impact of the criteria on the research object were calculated. Firstly, Table 9 presents the results of weight calculation for main criterion 12, and consequently, for all criteria from the created matrix, the calculation of the criteria weights are presented in Table 10. 
Table 9. The results of weight calculation of the criteria describing the research object

\begin{tabular}{lccccccccc}
\hline \multicolumn{1}{c}{ Criteria group } & 12 & 11 & 13 & 2 & 10 & 4 & 8 & 7 & Total \\
\hline $\begin{array}{l}\text { The relationship between the } \\
\text { main (twelfth) criterion with other } \\
\text { system's criteria }\end{array}$ & & +1 & +2 & +3 & +4 & +5 & +6 & +7 & $P_{1}=28$ \\
\hline \begin{tabular}{l} 
Weights of criteria group $w_{i}$ \\
\hline
\end{tabular} & 0.18 & 0.16 & 0.15 & 0.13 & 0.12 & 0.10 & 0.09 & 0.07 & $\sum_{i}^{n} w_{i}=1.0$ \\
\hline
\end{tabular}

Source: compiled by authors.

There can be seen distribution of total effectiveness of each criterion concerning technology transfer and value creation process performance.

Table 10. The calculation of the criteria weights by FARE method

\begin{tabular}{|c|c|c|c|c|c|c|c|c|c|c|c|}
\hline \multirow{2}{*}{$\begin{array}{l}\text { Criteria } \\
\text { group }\end{array}$} & \multicolumn{8}{|c|}{ Criteria group } & \multirow{2}{*}{$\begin{array}{c}\text { Total Effect } \\
\text { (Dependence) } P_{i}\end{array}$} & \multirow{2}{*}{$P_{i}^{f}$} & \multirow{2}{*}{$w_{i}$} \\
\hline & 12 & 11 & 13 & 2 & 10 & 4 & 8 & 7 & & & \\
\hline 12 & & +1 & +2 & +3 & +4 & +5 & +6 & +7 & +28 & +98 & 0.18 \\
\hline 11 & -1 & & +1 & +2 & +3 & +4 & +5 & +6 & +20 & +90 & 0.16 \\
\hline 13 & -2 & -1 & & +1 & +2 & +3 & +4 & +5 & +12 & +82 & 0.15 \\
\hline 2 & -3 & -2 & -1 & & +1 & +2 & +3 & +4 & +4 & +74 & 0.13 \\
\hline 10 & -4 & -3 & -2 & -1 & & +1 & +2 & +3 & -4 & +66 & 0.12 \\
\hline 4 & -5 & -4 & -3 & -2 & -1 & & +1 & +2 & -12 & +58 & 0.10 \\
\hline 8 & -6 & -5 & -4 & -3 & -2 & -1 & & +1 & -20 & +50 & 0.09 \\
\hline 7 & -7 & -6 & -5 & -4 & -3 & -2 & -1 & & -28 & +42 & 0.07 \\
\hline Total & -28 & -20 & -12 & -4 & +4 & 12 & 20 & +28 & 0 & 560 & 1 \\
\hline
\end{tabular}

Source: compiled by authors.

Weights of the highest 8 indicators that impact technology transfer as well as value creation performance was calculated and represented in Table 11.

III stage. When we have calculated weights of each criterion, and also collected value average data of each of those criteria for seven biggest Lithuanian universities from the period 2011-2013 year, we successfully ranked all the universities based on TOPSIS method. The idea was to find out how great, based on our chosen criteria, universities were influenced in their value creation process through technology transfer office performance assessment. Table 12 presents the results obtained:

The results have shown that the best results of technology transfer performance have UNI 3 (the first place), then UNI 2 (the second place) and UNI 1 (the third place).

In comparison with other studies (Fitzgerald, Cunningham 2016) we argued that the quantity of university patent applications (later converted to patents) have direct influence on technology transfer orientation. Many authors' research results confirmed that the policy of the country (Gerbin, Drnovšek 2013), e.g. financing (Audretsch et al. 2016; Ayoub et al. 2017) of patent procedures, also motivation tools (Keller 2004; (Araújo, Teixeira 2014) and accessibility of university (Huyghe et al. 2016; Boh et al. 2016) have significant effect on technology transfer process. 
Table 11. Weights were calculated based on FARE method and value average data were taken from seven biggest Lithuanian universities from the period 2011-2013 year

\begin{tabular}{lcccccccc}
\hline \multicolumn{1}{c}{ Criteria } & Uni 1 & Uni 2 & Uni 3 & Uni 4 & Uni 5 & Uni 6 & UNI 7 & $w_{i}$ \\
\hline $\begin{array}{l}\text { Income from contract } \\
\text { works (avg thsd EUR) }\end{array}$ & 2767.64 & 1541.01 & 718.13 & 79.03 & 1126.26 & 285.34 & 268.01 & 0.18 \\
\hline $\begin{array}{l}\text { Income from international } \\
\text { projects (avg thsd EUR) }\end{array}$ & 778.11 & 2338.2 & 1475.13 & 3394.35 & 3963.68 & 231.28 & 662.26 & 0.16 \\
\hline $\begin{array}{l}\text { Funding per one researcher } \\
\text { (avg thsd EUR) }\end{array}$ & 18.18 & 62.08 & 45.31 & 20.9 & 35.28 & 18.65 & 79.99 & 0.15 \\
\hline $\begin{array}{l}\text { European and international } \\
\text { patents applications (avg) }\end{array}$ & 2 & 1.3 & 6.3 & 0 & 0 & 0 & 0 & 0.13 \\
\hline $\begin{array}{l}\text { Income from national } \\
\text { projects (avg thsd EUR) }\end{array}$ & 343.2 & 4157.98 & 17051.1 & 1826.05 & 864.39 & 469.19 & 433.95 & 0.12 \\
\hline $\begin{array}{l}\text { The number of employees } \\
\text { at TTO (avg) }\end{array}$ & 1 & 10 & 1 & 2 & 0.3 & 12 & 0 & 0.10 \\
\hline $\begin{array}{l}\text { The number of researchers } \\
\text { at university (avg) }\end{array}$ & 219 & 149.7 & 422.7 & 248.7 & 240.7 & 53 & 17.3 & 0.09 \\
\hline $\begin{array}{l}\text { The number of } \\
\text { publications at university } \\
\text { (avg) }\end{array}$ & 1210 & 2053 & 1954 & 702 & 417 & 757 & 1192 & 0.07 \\
\hline
\end{tabular}

Source: compiled by authors from available financial reports.

Table 12. Technology transfer office performance assessment and ranking of universities

\begin{tabular}{ccc}
\hline Rank & Tech. number & Aggregate Value \\
\hline 1 & UNI 3 & 0.564 \\
\hline 2 & UNI 2 & 0.452 \\
\hline 3 & UNI 1 & 0.430 \\
\hline 4 & UNI 5 & 0.373 \\
\hline 5 & UNI 4 & 0.276 \\
\hline 6 & UNI 6 & 0.235 \\
\hline 7 & UNI 7 & 0.175 \\
\hline
\end{tabular}

Source: compiled by authors.

The more closely industry and science will work (Etzkowitz, Leydesdorff 2000; Sherwood, Covin 2008), the more useful innovations will be developed by scientists. Globalization process, international partners (Zhang, Gallagher 2016; Lee et al. 2017), international patenting and IP portfolio (Roberts 1999) could bring more revenue for university based on license or other commercialization way, what directly influence the technology transfer offices' performance results. Study shows, significant influence of contract works on the performance of technology transfer offices, as well as the positive influence of international and national projects on the high performance and created 
value for universities, similar to Huyghe et al. (2016), at the same time expanding network of university partners (Miller et al. 2016; Carlsson, Fridh 2002; Fritsch, Schwirten 1999). Experts response reflect science-business actuality, so universities should maintain active strategy (Battaglia et al. 2017; Fai et al. 2017) and build strong relationships and attract more "customers" (Lee et al. 2017) to university. While universities will have strong technology transfer office's staff, saturated market and absorptive capacity (Santoro, Bierly 2006), when industry will be ready for progress, then we can expect significant incomes from innovation industry to governmental budget.

The conducted research has also some limitations. Collected data and methods for collecting were different and it sets constraints on the adequacy of the model. Although the quality of data was appropriate. The analysis methods chosen for research allowed us to set the weights of technology transfer performance indicators (while experts ranked the most important indicators) and then rank universities by technology transfer performance results. Therefore, some factors were derived indirectly and with limitations, and they may lack some qualities considered in the theoretical part. There are multiple ways for further development of the model, first there is a need to elaborate reliable questionnaires for collecting the source data, second, other multicriteria decision methods could be used to improve the quality of obtained results.

\section{Conclusions}

The main purpose of this study was to develop the principles of the assessment of technology transfer activities and benchmarking of key indicators as well as to create basic multicriteria model to assess the effectiveness of technology transfer offices' activities. The study has proposed the methodology for evaluating the technology transfer performance as the way for value creation in the technology transfer process.

It was found that the most important indicators which show the performance of technology transfer office performance: 1) income from contract works; 2) income from international projects; 3) funding per one researcher (FTE). Next goes - the numbers of European and international patent applications; income from national projects; university-business cooperation encouraging providing services for industry and also realizing IP and know-how.

The methods (FARE, TOPSIS) used here allowed to rank universities with the best results. So, UNI 3 is the leader between valued 7 Lithuanian universities. Certainly, UNI 3 has the biggest number of students and also the biggest numbers number of national, international and contract works and the number of researchers - all these facts are important contribution to the best results of science production. UNI 2 has the biggest number of start-ups; however, it is not reflecting in incomes.

Research results showed that the number of students and GDP per capita, national patents and the number of start-ups have the lowest potential to impact the main 12 indicators; and the highest impact have incomes from national projects.

It was found that there is a positive relation between the efficiency of technology transfer office and the number of qualified employees, motivation systems, the trust between 
technology transfer office staff and scientists, the multicultural environment, excellent communication skills of technology transfer office, continues trainings and networking of technology transfer staff.

Implementing entrepreneurial policy is extremely important for innovation and commercialization activities. Universities should pay attention on developing these activities to increase technology transfer office performance results.

We fully agree with Burton (2008) statements, that Universities still have to be universities with the main mission as education value through the activities of study, teaching and research and transformation to become entrepreneurial takes about 10-15 years. So, the Government should give more time to learn how to be entrepreneurial university and invest for developing technology transfer office structures.

For the future research, it would be very useful to go deeper into the factors that influence technology transfer process staff for better results: motivation systems, particular environment, policy, funding systems, various participants within innovation process and other. Overall, our study confirmed the important roles of technology transfer offices for the cooperation between universities and industry for the success of innovation and commercialization activities.

\section{References}

Araújo, A. C.; Teixeira, A. A. C. 2014. Determinants of international technology transfer: an empirical analysis of the enterprise Europe network, Journal of Technology Management and Innovation 9(3): 120-134. https://doi.org/10.4067/S0718-27242014000300009

Arvanitis, S; Woerter, M. 2009. Firms transfer strategies with universities and the relationship with firm's innovation performance, Industrial and Corporate Change 18(6): 1067-1106.

https://doi.org/10.1093/icc/dtp029

Audretsch, D. B.; Lehmann, E. E.; Paleari, S.; Vismara, S. 2016. Entrepreneurial finance and technology transfer, The Journal of Technology Transfer 41(1): 1-9.

https://doi.org/10.1007/s10961-014-9381-8

Audretsch, D. B.; Lehmann, E. E.; Link, A. N.; Starnecker, A. 2013. Technology transfer in a global economy. Springer.

Ayoub, M. R.; Gottschalk, S.; Müller, B. 2017. Impact of public seed-funding on academic spinoffs, The Journal of Technology Transfer 42(5): 1100-1124.

https://doi.org/10.1007/s10961-016-9476-5

Baležentis, T.; Baležentis, A. 2014. A survey on development and applications of the multicriteria decision-making method MULTIMOORA, Journal of Multi-Criteria Decision Analysis 21: 209-222. https://doi.org/10.1002/mcda.1501

Battaglia, D.; Landoni, P.; Rizzitelli, F. 2017. Organizational structures for external growth of university technology transfer offices: an explorative analysis, Technological Forecasting and Social Change 123: 45-56. https://doi.org/10.1016/j.techfore.2017.06.017

Behzadian, M.; Otaghsara, S. K.; Yazdani, M.; Ignatius, J. 2012. A state-of the-art survey of TOPSIS applications, Expert Systems with Applications 39(17): 13051-13069.

https://doi.org/10.1016/j.eswa.2012.05.056

Boh, W. F.; De-Haan, U.; Strom, R. 2016. University technology transfer through entrepreneurship: faculty and students in spinoffs, The Journal of Technology Transfer 41(4): 661-669.

https://doi.org/10.1007/s10961-015-9399-6 
Breznitz, S. M.; Etzkowitz, H. (Eds.). 2017. University technology transfer: the globalization of academic innovation. Routledge.

Burton, R. C. 2008. Creating entrepreneurial universities. Organizational pathways of transformation. Emerald Group publishing limited.

Carlsson, B.; Fridh, A. 2002. Technology transfer in United States universities, Journal of Evolutionary Economics (Special issue) 12(1): 199-232. https://doi.org/10.1007/s00191-002-0105-0

Chatterji, M. (Ed.). 2016. Technology transfer in the developing countries. Springer.

Choudhury, K. 2015. Evaluating customer-perceived service quality in business management education in India. A study in TOPSIS modelling, Asia Pacific Journal of Marketing and Logistics 27(2): 208-225. https://doi.org/10.1108/APJML-04-2014-0065

Ding, L.; Zeng, Y. 2015. Evaluation of Chinese higher education by TOPSIS and IEW - the case of 68 universities belonging to the Ministry of Education in China, China Economic Review 36: 341-358. https://doi.org/10.1016/j.chieco.2015.05.007

Etzkowitz, H.; Göktepe-Hultén, D. 2016. De-reifying technology transfer metrics: to address the stages and phases of TTO development, in S. M. Breznitz, H.Etzkowitz (Eds.). University Technology Transfer: the globalization of academic innovation. Routledge Studies in Global Competition. Abingdon, UK: Routledge, 84-101.

Etzkowitz, H.; Leydesdorff, L. 2000. The dynamics of innovation: from national systems and "Mode 2" to a triple helix of university-industry-government relations, Research Policy 29(2): 109-123. https://doi.org/10.1016/S0048-7333(99)00055-4

Fai, F.; De Beer, C.; Schutte, C. 2017. A novel technology transfer office typology based on lessons learnt from the UK: recommendations for developing countries, 95-102.

Fitzgerald, C.; Cunningham, J. A. 2016. Inside the university technology transfer office: mission statement analysis, The Journal of Technology Transfer 41(5): 1235-1246.

https://doi.org/10.1007/s10961-015-9419-6

Fritsch, M.; Schwirten, C. 1999. Enterprise-university co-operation and the role of public research institutions in regional innovation system, Industry and Innovation 6(1): 69-83.

https://doi.org/10.1080/13662719900000005

Gerbin, A.; Drnovšek, M. 2013. How do university IPRs and R\&D funding mechanisms affect innovation performance in the healthcare biotechnology industry? Evidence from Europe and the USA, Periodicum Biologorum 115(1): 79-95.

Ginevičius, R. 2011. A new determining method for the criteria weights in multicriteria evaluation, International Journal of Information Technology \& Decision Making 10(6): 1067-1095. https://doi.org/10.1142/S0219622011004713

Gregorio, D. D.; Shane, S. 2003. Why do some universities generate more start-ups than others?, Research Policy 32(2): 209-227. https://doi.org/10.1016/S0048-7333(02)00097-5

Hashemkhani Zolfani, S.; Maknoon, R.; Zavadskas, E. K. 2016a. An introduction to prospective multiple attribute decision making (PMADM), Technological and Economic Development of Economy 22(2): 309-326. https://doi.org/10.3846/20294913.2016.1150363

Hashemkhani Zolfani, S.; Maknoon, R.; Zavadskas, E. K. 2016b. Multiple attribute decision making (MADM) based scenarios, International Journal of Strategic Property Management 20(1): 101-111. https://doi.org/10.3846/1648715X.2015.1132487

Hui-I, F.; Chia-Shen, Ch.; Chuan-Hung, W.; Hsueh-Chiao, Ch. 2012. The role of intellectual capital and university technology transfer offices in university-based technology transfer, The Service Industries Journal 32(6): 899-917. https://doi.org/10.1080/02642069.2010.545883

Hulsbeck, M.; Lehmann, E.; Starnecker, A. 2011. Performance of technology transfer offices in Germany, Journal of Technology Transfer 38(3): 199-215.

https://doi.org/10.1007/s10961-011-9243-6 
Huyghe, A.; Knockaert, M.; Piva, E.; Wright, M. 2016. Are researchers deliberately bypassing the technology transfer office? An analysis of TTO awareness, Small Business Economics 47(3): 589-607. https://doi.org/10.1007/s11187-016-9757-2

Hwang, C. L.; Yoon, K. 1981. Multiple attribute decision making: methods and applications. New York: Springer-Verlag. https://doi.org/10.1007/978-3-642-48318-9

Ivanauskas, F.; Kregzde, A.; Pikturna, A. 2015. Analysing the funding changes of Lithuanian higher education, Transformations in Business \& Economics 14(3): 38-53.

Kabak, M.; Dagdeviren, M. 2014. A hybrid MCDM approach to assess the sustainability of students' preferences for university selection, Technological and Economic Development of Economy 20(3): 391-418. https://doi.org/10.3846/20294913.2014.883340

Kahraman, C.; Suder, A.; Cebi, S. 2013. Fuzzy multi-criteria and multi-experts evaluation of government investments in higher education: the case of Turkey, Technological and Economic Development of Economy 19(4): 549-569. https://doi.org/10.3846/20294913.2013.837110

Keller, W. 2004. International technology diffusion, Journal of Economic Literature 42(3): 752 782. https://doi.org/10.1257/0022051042177685

Keshavarz Ghorabaee, M.; Zavadskas, E. K.; Amiri, M.; Antucheviciene, J. 2016. Evaluation by an area-based method of ranking interval type-2 fuzzy sets (Eamrit-2f) for multi-criteria group decision-making, Transformations in Business \& Economics 15(3): 76-95.

Lee, S.; Kim, B. S.; Kim, Y.; Kim, W.; Ahn, W. 2017. The framework for factors affecting technology transfer for suppliers and buyers of technology in Korea, Technology Analysis \& Strategic Management 1-14. https://doi.org/10.1080/09537325.2017.1297787

Madic, M.; Antucheviciene, J.; Radovanovic, M.; Petkovic, D. 2016. Determination of manufacturing process conditions by using MCDM methods: application in laser cutting, Engineering Economics 27(2): 144-150.

Mainardes, E. W.; Ferreira, J. J.; Raposo, M. L. 2015. Strategy and strategic management concepts: are they recognised by management students? E\&M Ekonomie a Management 17(1): 43-61. https://doi.org/10.15240/tul/001/2014-1-004

Mardani, A.; Jusoh, A.; Nor, K. M. D.; Zakwan, N.; Valipour, A. 2015a. Multiple criteria decision-making techniques and their applications - a review of the literature from 2000 to 2014, Economic Research-Ekonomska Istrazivanja 28(1): 516-571.

https://doi.org/10.1080/1331677X.2015.1075139

Mardani, A.; Jusoh, A.; Zavadskas, E. K.; Khalifah, Z.; Nor, K. M. 2015b. Application of multiple-criteria decision-making techniques and approaches to evaluating of service quality: a systematic review of the literature, Journal of Business Economics and Management 16(5): 1034-1068. https://doi.org/10.3846/16111699.2015.1095233

Miller, K.; McAdam, R.; McAdam, M. 2016. A systematic literature review of university technology transfer from a quadruple helix perspective: toward a research agenda, $R \& D$ Management: 1-18. https://doi.org/10.1111/radm.12228

Nazarko, J.; Saparauskas, J. 2014. Application of DEA method in efficiency evaluation of public higher education institutions, Technological and Economic Development of Economy 20(1): 25-44. https://doi.org/10.3846/20294913.2014.837116

Ouyang, Q. C.; Spohrer, J.; Caraballo, J.; Davis, D.; Perelgut, S.; Mindel, M.; ... Subbanna, S. 2017. Collaborative innovation centers (CICs): towards smart service system design, in Serviceology for Smart Service System. Japan: Springer, 385-391.

Pfeffer, J. 1995. Producing sustainable competitive advantage through the effective management of people, Academy of Management Executive 19(4): 55-69.

https://doi.org/10.5465/AME.1995.9503133495

Roberts, H. 1999. The control of intangibles in the knowledge-intensive firm. Paper presented at the $22^{\text {nd }}$ Annual Congress of the European Accounting Association, Bordeaux. 
Santoro, M. D.; Bierly, III, P. E. 2006. Facilitators of knowledge transfer in university-industry collaborations: a knowledge-based perspective, IEEE Transactions on Engineering Management 53(4): 495-507. https://doi.org/10.1109/TEM.2006.883707

Sherwood, A. L.; Covin, J. G. 2008. Knowledge acquisition in university-industry alliances: an empirical investigation from a learning theory perspective, Journal of Product Innovation Management 25(2): 162-179. https://doi.org/10.1111/j.1540-5885.2008.00292.x

Song, J.; Zheng, J. 2015. The application of Grey-TOPSIS method on teaching quality evaluation of the higher education, International Journal of Emerging Technologies in Learning 10(8): 42-45. https://doi.org/10.3991/ijet.v10i8.5219

Stankevicienè, J.; Vaiciukeviciute, A. 2016. Value creation for stakeholders in higher education management, E\&M Ekonomie a Management 19(1): 17-32.

https://doi.org/10.15240/tul/001/2016-1-002

Stefano, N. M.; Casarotto Filho, N.; Vergara, L. G. L.; Rocha, R. U. G. 2015. COPRAS (Complex Proportional Assessment): State of the Art Research and Its Applications. IEEE Latin America transactions, 3899-3906. https://doi.org/10.1109/TLA.2015.7404925

Thursby, J. G.; Thursby, M. C 2001. Industry perspectives on licensing university technologies: sources and problems, Industry and Higher Education 15(4).

https://doi.org/10.5367/000000001101295786

Van Dooren, W.; Bouckaert, G.; Halligan, J. 2010. Performance management in the public Sector. Routledge: London and New York, 9-63.

Wang T.-C.; Chang, T.-H. 2007. Application of TOPSIS in evaluating initial training aircraft under a fuzzy environment, Expert Systems with Applications 33(4): 870-880.

https://doi.org/10.1016/j.eswa.2006.07.003

Zavadskas, E. K.; Mardani, A.; Turskis, Z.; Jusoh, A.; Nor, K. M. 2016. Development of TOPSIS method to solve complicated decision-making problems - an overview on developments from 2000 to 2015, International Journal of Information Technology \& Decision Making 15(03): 645-682. https://doi.org/10.1142/S0219622016300019

Zavadskas, E. K.; Turskis, Z.; Kildiene, S. 2014. State of art surveys of overviews on MCDM/ MADM methods, Technological and Economic Development of Economy 20(1): 165-179.

https://doi.org/10.3846/20294913.2014.892037

Zhang, F.; Gallagher, K. S. 2016. Innovation and technology transfer through global value chains: evidence from China's PV industry, Energy Policy 94: 191-203.

https://doi.org/10.1016/j.enpol.2016.04.014

Zolfani, S. H.; Salimi, J.; Maknoon, R.; Kildiene, S. 2015. Technology foresight about R\&D projects selection; application of SWARA method at the policy making level, Engineering Economics 26(5): 571-580.

Jelena STANKEVIČIENE் is a Professor at the Department of Financial Engineering at Vilnius Gediminas Technical University (Lithuania). Her main research topics include financial management for value creation, value engineering, assets and liability management, regulation of financial institution, higher education management.

Lidija KRAUJALIENE is a PhD student at the Department of Financial Engineering at Vilnius Gediminas Technical University (Lithuania). Her research focuses on the performance management of technology transfer process in higher education institutions.

Agnè VAICIUKEVIČİŪTÉ is a PhD student at the Department of Financial Engineering at Vilnius Gediminas Technical University (Lithuania). Her scientific interests concentrate on research methodology of higher education management, value creation for stakeholders and the economic impact of higher education. 